\title{
JOURNAL_RU COMPANY GROUP "INTELLEKT"
}

\author{
Лоренц В. В. \\ Омский Государственный педагогический Университет \\ Россия, г. Омск
}

DOI:10.18411/2015-08-4-1-6-9

«Вертикальная» и «горизонтальная» академическая мобильность как актуальная характеристика современного образования

Участие России в построении единого общеевропейского образовательного пространства и рекомендации Болонского процесса являются одними из внешних факторов, обусловивших внедрение новых образовательных стандартов. Разработка и реализация третьего поколения государственных образовательных стандартов высшего профессионального образования в РФ ведется в соответствии с Комплексом мероприятий по реализации приоритетных направлений развития системы образования РФ и Планом мероприятий по реализации положений Болонской декларации в системе высшего профессионального образования Российской Федерации.

Одним из важных требований является наличие основной образовательной программы высшего учебного заведения, которая должна содержать дисциплины по выбору студента в объеме не менее одной трети вариативной части каждого цикла. ВУЗ обязан обеспечить студентам реальную возможность участвовать в формировании своей программы обучения, которую можно назвать индивидуально-образовательным маршрутом или образовательной траекторией. В своей диссертации мы указывали на условия, которые необходимо создать для эффективного проектирования и реализации 
обучения по индивидуально-образовательным маршрутам, а также представили типы возможных образовательных маршрутов студентов [5].

На основе компетентностного подхода ФГОС ВПО предусматривает новые требования к результатам освоения образовательных программ бакалавра, специалиста и магистра. В качестве основного объекта оценки выступают профессиональные и общекультурные компетенции, под которыми понимаются способности применять знания, умения и личностные качества для успешной деятельности в определенной области. Обязательным компонентом становится научно-исследовательская работа студента. Трудоемкость программы измеряется не в часах, а в зачетных единицах. В связи с этим и меняется система оценивания - осуществляется переход на балльнорейтинговую систему оценки.

Таким образом, мы можем говорить о том, что внедрение ФГОС ВПО третьего поколения это важный и ответственный момент для всего Российского высшего профессионального образования. Реализации образовательных программ третьего поколения предопределяет необходимость изменения не только содержания подготовки кадров, но и подходов к поиску форм организации учебного процесса, в которых предусматривается усиление роли и постоянной оптимизации самостоятельной работы студентов, увеличение академическиой активности и мобильности. Также реализуется новая тенденции в образовании - прикладной характер, практическая ориентация образовательного процесса. Появляется новая специальность - прикладной бакалавриат, где увеличивается доля практических, лабораторных занятий. Новые условия диктуют необходимость модернизации технологий обучения, что существенно меняет подходы к учебно-методическому и организационнотехническому обеспечению учебного процесса.

В связи с этим, академической мобильности студентов, преподавателей и административного персонала вузов в рамках Болонского процесса придается большое значение. Академической мобильностью является перемещение кого-либо, имеющего отношение к образованию, на определенный (обычно от 
семестра до года) период в другое образовательное учреждение (в своей стране или за рубежом) для обучения, преподавания или проведения исследований, после чего учащийся, преподаватель или исследователь возвращается в свое основное учебное заведение. Такое определение академической мобильности дано в рекомендациях Комитета министров Совета Европы в 1996 г.

В Совместной декларации четырех министров образования (Сорбонна, 1998 г.) указано:«..как на первом уровне высшего образования, так и на втором, студентов следует поощрять, проводить, по меньшей мере, один семестр в университетах за пределами своей страны. В то же самое время все больше преподавателей и исследователей должны работать в европейских странах, помимо своей собственной» [6]. Болонская декларация так формулирует задачи в данной области: Способствовать мобильности за счет преодоления препятствий, эффективному осуществлению свободы передвижения, уделяя особое внимание:

- для студентов - доступу к учебным заведениям и соответствующим услугам;

• для преподавателей, исследователей и административного персонала признанию и подтверждению периодов, проведенных в европейских странах, в целях научных исследований, преподавания и переподготовки, не нарушая их статуса и законных прав.

Берлинское коммюнике (2003 г.) определяет мобильность студентов, академического и административного персонала основой создания европейского пространства высшего образования. Главная цель мобильности дать студенту возможность получить разностороннее «европейское» образование по выбранному направлению подготовки, обеспечить ему доступ в признанные центры знаний, где традиционно формировались ведущие научные школы, расширить познания студента во всех областях европейской культуры, привить ему чувство гражданина Европы. Академическая мобильность отличается от традиционных зарубежных стажировок прежде всего тем, что, во-первых, студенты едут учиться за рубеж хоть и на ограниченные, но 
длительные сроки - от семестра до учебного года, и, во-вторых, во время таких стажировок они учатся полноценно, не только изучают язык и отдельные дисциплины, а проходят полный семестровый или годичный курс, который им засчитывается по возвращении в базовый вуз.

В Болонском процессе различают два вида академической мобильности: «вертикальную» и «горизонтальную». Под вертикальной мобильностью подразумевают полное обучение студента на степень в зарубежном вузе, под горизонтальной — обучение там в течение ограниченного периода (семестра, учебного года). При этом виртуальная мобильность не является заменой физической мобильности.

Документы Болонского процесса постоянно призывают европейские университеты инициировать программы финансовой помощи студентам в целях поддержания их европейской академической мобильности. Свободная мобильность всех участников образовательного процесса - студентов, преподавателей, исследователей, администраторов - должна стать одним из главных условий повышения конкурентоспособности и привлекательности образования в европейских университетах.

Таким образом, интернационализация определяет развитие систем высшего образования в мире. Под интернационализацией в сфере высшего образования принято понимать объективный процесс, при котором цели, функции и организация предоставления образовательных услуг приобретают международное измерение.

Интернационализация образования включает следующие формы международного сотрудничества:

1. индивидуальная мобильность: мобильность студентов или профессорскопреподавательского состава в образовательных целях;

2. мобильность образовательных программ и институциональная мобильность, формирование новых международных стандартов образовательных программ; 
3. интеграция в учебные программы международного измерения и образовательных стандартов;

4. институциональное партнерство: создание стратегических образовательных альянсов [2, с.8].

В настоящее время вполне очевидно, что на мировом рынке высшего образования в условиях интернационализации разворачивается «соревнование за мировой талант». Академическая мобильность студентов является одной из самых наблюдаемых и наглядных форм интернационализации высшего образования. Во многих странах тема международной студенческой мобильности стала одной из ключевых в политике, как с точки зрения отправления специалистов за рубеж, так и с точки зрения привлечения в страну работников научной сферы или даже как потенциальных эмигрантов с высокой квалификацией.

Согласно прогнозам, международная студенческая мобильность к 2020г. достигнет 5,8 млн. человек и 8 млн. — к 2025г. [3, с.117]

Рост международной мобильности студентов обусловлен различными факторами. Наиболее значимыми являются: привлекательность интеллектуального, культурного и политического климата в стране предполагаемого обучения, определенная легкость доступа к высшему образованию за рубежом, включая расходы на обучение и язык обучения, общность языка и религии принимающей стороны, политическая стабильность и безопасность, географическая близость и наличие родственников и друзей в стране обучения. Не менее важными факторами желания молодых людей выехать на обучение за рубеж являются репутация и статус вузов, репутация образовательных программ и их доступность.

Академическая мобильность стала неотъемлемой чертой современного образования. Поэтому существует реальная необходимость в изучении и анализе всех сторон этого процесса с целью дальнейшего использования его российской высшей школой для совершенствования своей системы образования и интересов России в целом. 


\section{Список используемых источников информации}

1. Байденко В.И. Выявление состава компетенций выпускников вузов как необходимый этап проектирования ФГОС ВПО нового поколения. Режим доступа :http://dap.vvsu.ru.

2. Дударева Н.А., Интернационализация российской системы высшего образования: экспорт образовательных услуг (по материалам Всероссийского совещания проректоров по международной деятельности). М., 2009

3. Высшее образование для общества, основанного на знании. Часть 2: особенности высшего образования: равенство, инновации, рынок труда, интернационализация. Вестник международных организаций,2010, № 3.

4. Сафонова М.А., Социальная организация образовательных миграций. СПб., 2011

5. Лоренц В.В. Проектирование индивидуально-образовательного маршрута как условие подготовки будущего специалиста к профессиональной деятельности. - дисс. на соиск. уч. степ. канд. пед. н./Омск, 2001.

6. Сорбонская декларация (1998 г). Совместное заявление о гармонизации архитектуры европейской системы высшего образования. Режим доступа: http://www.france-jus.ru/upload/docs/Declaration_Sorbonne.pdf 